\title{
Cristalografia e Função de Canais Membranares
}

\section{Cristalografia e Função de Canais Membranares}

No início do mês de Outubro de 2003 foram anunciados os nomes dos dois cientistas americanos laureados com - Prémio Nobel da Química, pelas "suas descobertas relacionadas com canais existentes nas membranas celulares". Peter Agre da Universidade de Johns Hopkins em Baltimore "pela descoberta do canal de água" e Rodrick MacKinnon da Universidade de Rockefeller em Nova lorque "por estudos estruturais e mecanísticos de canais iónicos". Ao ouvir pela rádio esta notícia fiquei particu- larmente emocionada pois toda a minha vida científica tem andado à volta do transporte biológico. Embarquei neste campo logo no início da década de setenta, enquanto estagiária no Laboratório de Fisiologia do Instituto Gulbenkian de Ciência a trabalhar com o Prof. Hugo Gil Ferreira em transporte biológico. Terminado o meu estágio, licenciei-me em Eng. Química no IST e fui doutorar-me em Fisiologia para a Universidade de Berkeley onde conheci o Prof. Robert Macey que trabalhava em canais de água e com quem desde então tenho mantido estreita colaboração.

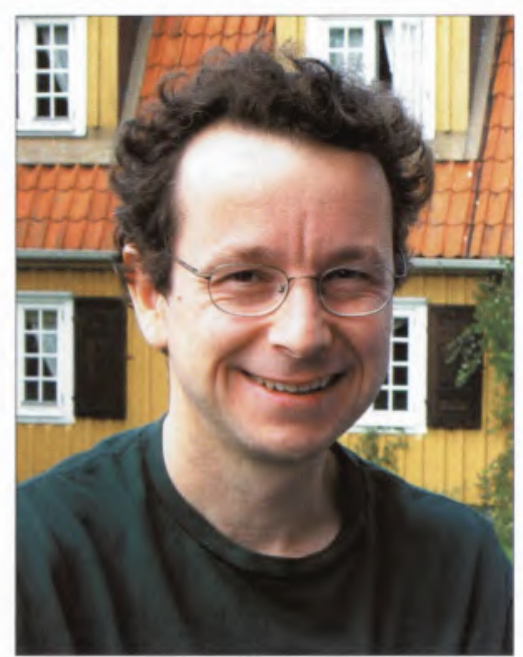

Rodrick Mackinnon

"por estudos estruturais e mecanísticos de canais iónicos"

\section{Canais Iónicos - Rodrick Mackinnon}

Nos organismos pluricelulares os compartimentos intra e extracelulares, embora sendo geralmente isotónicos (igual concentração de água), são electrólitos de composição distinta onde se verifica uma distribuição assimétrica de várias espécies com particular relevância para o $\mathrm{K}^{+}$e o $\mathrm{Na}^{+}$. Os gradientes de concentração destes iões são mantidos à custa da operação de um sistema de transporte activo membranar (bomba de $\mathrm{Na}^{+}$) que, consumindo energia metabólica das células, estabelece estes gradientes de tal modo que $\left[\mathrm{K}^{+}\right]_{\text {in }}>>\left[\mathrm{K}^{+}\right]_{\text {ex }}$ e que $\left[\mathrm{Na}^{+}\right]_{\text {in }}<<\left[\mathrm{Na}^{*}\right]_{\text {ex }}$. Praticamente todas as membranas celulares têm canais específicos para estes iões sendo, pois, permeáveis ao $\mathrm{K}^{+}$e ao $\mathrm{Na}^{+}$. A diferença de potencial eléctrico através das membranas biológicas é largamente determinada pela soma ponderada dos potenciais de Nernst dos iões em presença, para os quais a membrana é permeável e, de entre estes, o potencial de difusão do $\mathrm{K}^{+}$ é dominante. $\mathrm{O}$ potencial de membrana das células excitáveis (nervo e músculo) é de cerca de $-70 \mathrm{mV}$. As permeabilidades para o sódio e para o potássio destas células alteram-se transitoriamente na presença de estímulos químicos e físicos e, em especial, quando o potencial de membrana varia. Estas variações do potencial de membrana determinam alterações na conformação dos canais iónicos e variações dramáticas na sua permeabilidade, servindo estas alterações de sinais eléctricos. Esta capacidade é utilizada pelo sistema nervoso para iniciar, processar e transmitir mensagens.

O trabalho de Rodrick MacKinnon situase ao nivel destes canais iónicos tendo conseguido resolver a estrutura do canal de $\mathrm{K}^{+}$sensível à voltagem e permitindo assim a visualização dos mecanismos moleculares subjacentes à condução, especificidade e activação destes canais.

\section{Electrofisiologia de canais de $\mathrm{K}^{+}$}

A existência de canais iónicos especificos para o $\mathrm{Na}^{+}$e para o $\mathrm{K}^{+}$nas membranas de células excitáveis foi postula-

\footnotetext{
- Departamento de Quimica, Centro de Quimica Fina e Biotecnologia, Faculdade de Ciências e Tecnologia, Universidade Nova de Lisboa, email: tfm@dq.fct.unl.pt
} 
da nos anos cinquenta por Hodgkin, Huxley e Katz, quando conseguiram registar o comportamento do axónio gigante da lula após inserção no seu interior de um fio de prata. Verificaram que a variação de potencial de membrana medida (potencial de acção) estava directamente relacionada com correntes iónicas (iões $\mathrm{Na}^{*}$ a entrar na célula e iões $\mathrm{K}^{+}$a sair da célula), tendo concluído que, sendo a camada bilipídica muito impermeável a iões, estes teriam de passar através de poros aquosos existentes na membrana celular. Hodgkin e Huxley ganharam o Nobel da Medicina em 1963 pela caracterização rigorosa que fizeram do potencial de acção, descrevendo a cinética do transporte através de canais iónicos do nervo, que consideraram serem específicos para os respectivos iōes, serem activados por voltagem, possuírem portões (ou válvulas) activáveis ou inactiváveis. Assim, a existência de canais específicos de dimensōes moleculares foi postulada muitas décadas antes da possibilidade da sua visualização e originou um campo científico próprio, o da Electrofisiologia. onde a caracterização dos canais é feita a partir da medição de correntes transmembranares em condições experimentais bem determinadas, na presença e ausência de inibidores específicos (1). Este campo ganhou um enorme impulso quando Neher e Sackmann (Nobel de Medicina em 1991) desenvolveram uma técnica a nivel molecular que permitiu a detecção de correntes de canais isolados e consequentemente a sua caracterização individual. A técnica de retalho controlado (patch clamp) baseia-se na formação de um selo na ponta de uma pipeta de vidro (1 um de diâmetro) quando esta se encosta à superfície da membrana, ficando a ponta revestida por um retalho de membrana com um número diminuto de canais.

A identificação molecular destes canais, a proposta para a existência de filtro de selectividade e a verificação experimental da existência de portões de activação datam dos anos 60 e 70 .

No final da década de oitenta conseguiu clonar-se pela primeira vez os genes responsáveis pelas várias proteinas componentes dos canais de $\mathrm{K} \cdot$ da mosca da fruta e nos últimos dez anos foram identificados os mesmos genes numa grande variedade de organismos, o que permitiu postular que os canais de $\mathrm{K}^{*}$ de diferentes organismos devem ter estruturas idênticas. Por variadas experiências de mutagénese puderam ainda ser identificadas determinadas regiões do canal envolvidas em funções específicas.

MacKinnon começou em 1989 a sua carreira de electrofisiologista tendo escolhido estudar o canal de $\mathrm{K}$. por, segundo ele, ser na altura um dos menos conhecidos. Caracterizou a inibição do canal por uma toxina extraída do veneno dos escorpiões e concluiu que esta actuava directamente na zona do poro do canal e, por indução de mutações no gene em localizações muito precisas, determinou a região da proteina com capacidade de ligação ao K: Em 1996, com larga experiência em electrofisiologia e biologia molecular decidiu enveredar por outras técnicas, a cristalografia de RX, que the permitiriam obter a estrutura tridimensional do canal.

Assim, antes de se ter acesso à estrutura do canal de K da bactéria Streptomyces lividans obtida em 1998 por Rodrik Mackinnon e seus colaboradores, já se sabia que os canais eram especificos para $\mathrm{K}^{*}$ (permeáveis a Rb* e $\mathrm{Cs}^{*}$ e impermeáveis a iōes mais pequenos como o $\mathrm{Na}^{*}$ e $\mathrm{Li}^{+}$), já havia sido proposta a existência de um filtro de selectividade do canal (zona mais estreita do canal), um mecanismo de transporte em fila única dos iões dentro do filtro (previsto por Keynes), a desidratação dos iões antes da sua entrada no filtro (previsto por Hille) e a existência de grupos dentro do filtro que estabelecessem interacções com o ião $\mathrm{K}$ - tornando assim energeticamente favorável a sua entrada no filtro. Sabia-se que o canal rectificava, isto é, para as mesmas condições experimentais o fluxo de saída de iões era muito mais elevado do que o de entrada e era conhecido um inibidor específico de todos os canais de $\mathrm{K}$, o ião de tetraetil amónio (TEA). Já tinha sido identificada por vários investigadores, incluindo Mackinnon, a sequência de aminoácidos da parede do filtro, considerada a "assinatura" característica do canal de $\mathrm{K}$ ' conservada ao longo da evolução, assim como a existência de vários resíduos carregados positivamente relacionados com o sensor de voltagem do canal. Já se sabia que o canal era uma proteina tetramérica de monómeros idênticos, e que cada monómero continha a "assinatura". Faltava a visualização da estrutura para se poder compreender os mecanismos envolvidos na selectividade, na condução rápida ( $\approx$ $10^{9}$ iões $\mathrm{s}^{4}$ no pico das correntes, 50 vezes superior ao valor "turn over" da anidrase carbónica, considerado o valor mais elevado de todas as enzimas) e na sensibilidade do canal à voltagem, o que só seria possivel após obtenção da estrutura tridimensional do canal por cristalografia de RX. Em 1996 a perspectiva de sucesso na obtenção de estruturas cristalográficas de proteínas membranares era ainda muito longinqua, mesmo para especialistas neste campo.

Foi com esse objectivo especifico que em 1996 Rodrik Mackinnon, um electrofisiologista com ampla experiência em biologia molecular, mas sem nenhuma experiência feita em cristalografia dos RX, se transferiu da Universidade de Harvard, onde era professor, para a Universidade de Rockefeller. Segundo declarou numa entrevista, a Universidade de Rockefeller aceitou o risco de o contratar, sabendo que o seu projecto de determinação da estrutura do canal de $\mathrm{K}^{*}$ era extremamente ambicioso e de muito difícil execução e que, embora ele fosse um cientista com provas dadas, não tinha currículo feito nas técnicas essenciais à prossecução do projecto a que se propunha.

O grande desafio, que MacKinnon e sua equipa tiveram que enfrentar, foi o de conseguir estabelecer as condiçōes experimentais para a obtenção de cristais de boa qualidade de uma proteina membranar. Escolheram trabalhar com bactérias que expressassem canais de $\mathrm{K}^{+}$pois estas são fáceis de produzir em grandes quantidades. Para garantir a manutenção da estrutura do canal, os passos seguintes requeriam que os canais fossem extraídos das membranas ainda ligados aos seus lipidos nativos, e que os cristais fossem obtidos antes de ter havido qualquer dissociação destes. 

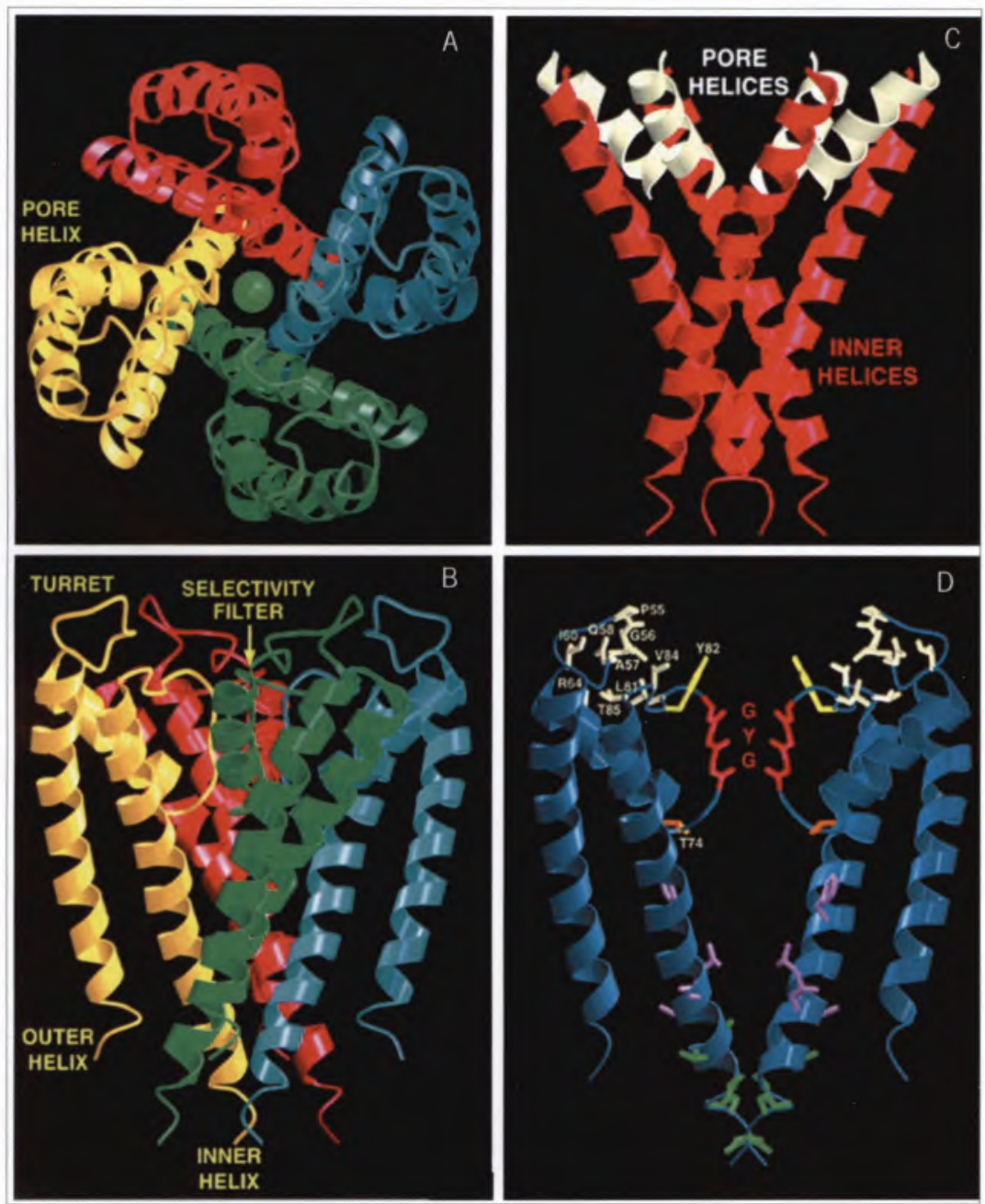

figura 1: Vistas do tetrâmero KcsA K': Nos painéis $\mathrm{A}$ (vista de topo) e B (vista lateral) cada monómero está representado a uma cor C. Vista lateral só das meias hélices e das hélices internas que se entrecruzam, S6. D. Vista lateral após remoção de duas subunidades de modo a tornar-se visível a regiâo da "assinatura" (Retirada da referência 2)

Ao longo de todo o processo foi a sua grande experiência como electrofisiologista que permitiu que, em sucessivas etapas, a funcionalidade dos canais fosse sempre verificada. MacKinnon refere que a parte mais difícil de ultrapassar foi a da optimização das condições experimentais pois o número de parâmetros a ajustar era enorme. Envolvia testar uma multiplicidade de condições o que poderia levar muitos anos (cerca de 900 condições experimentais diferentes a 2 temperaturas diferentes e com 10 detergentes diferentes). Felizmente, segundo ele, a optimização foi possível após dois anos de trabalho árduo de toda a sua equipa!

\section{Estrutura do canal de $\mathrm{K}^{+}$obtida por Rodrick MacKinnon}

A determinação da estrutura cristalina do canal de K+ da bactéria Streptomyces lividans apareceu na revista Science em Abril de 1998 (2), dois anos após a transferência de Mackinnon para a Universi- dade de Rockefeller. Mackinnon relatou à revista Nature em Julho de 2002, que no primeiro dia do ano de 1998 acordou com a sensação estranha de que o "seu momento de eureka" tinha sido só um sonho! Durante a madrugada anterior tinha passado largas horas sozinho a processar dados da estrutura do canal. Após cada iteração, o canal aparecia-lhe cada vez mais nítido tendo a dada altura começado a emergir as imagens dos iões $\mathrm{K}^{+}$alinhados dentro do filtro, tal como tinha sido previsto há 50 anos atrás por Hodgkin e Keynes! Mackinnon confidenciou ter ficado perplexo e muito entusiasmado com esta descoberta e ao mesmo tempo desanimado por não a poder partilhar com ninguém! Recordou então que muitos colegas seus, dois anos antes, Ihe tinham vaticinado que seria quase impossivel que ele pudesse resolver a estrutura do canal de $\mathrm{K}$ !

A estrutura do canal de $\mathrm{K}^{+}$da bactéria Streptomyces lividans (KcsA $\mathrm{K}^{+}$) permitiu a visualização dos mecanismos mo- leculares envolvidos na selectividade dos canais e na condução rápida dos iões, resolvendo assim o aparente paradoxo da compatibilidade entre a grande afinidade observada versus as elevadíssimas taxas de permeação medidas. A resolução desta estrutura permitiu também explicar o fenómeno da rectificação do canal, isto é, a diferença entre as taxas de permeação observadas quando o movimento dos iões se processa de dentro para fora ou em sentido contrário. Só em 2003 apareceram na revista Nature outros artigos da equipa de MacKinnon que elucidam as bases moleculares do mecanismo de activação dos canais de $\mathrm{K}$ + sensíveis à voltagem, os da arqueo bactéria termofilica Aeropyrum pernix (KvAP K+).

Sabe-se que existem duas variedades de canais de $\mathrm{K}^{+}$, uma mais complexa que contém 6 segmentos transmembranares por subunidade (S1 a S6), de que é exemplo o KvAP K+, e outra que contém só 2 ( 55 e S6), como o KcsA K*. 

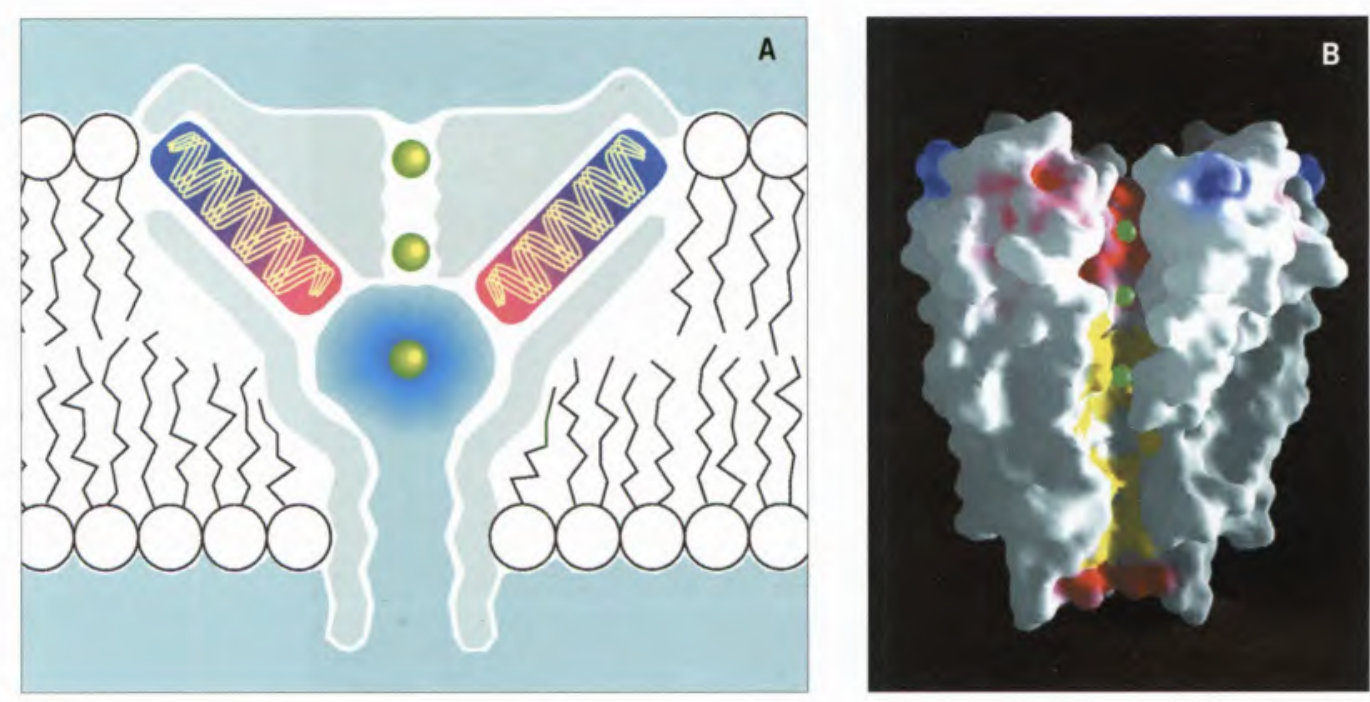

figura 2 Visão do interior do canal com 2 iões no filtro de selectividade e 1 no interior da cavidade central. A. Esquema que mostra os dois mecanismos de estabilização do $\mathrm{K}^{*}$ no interior do canal: a orientação dos pólos negativos (cor vermelha) das duas meias hélices para o interior do canal com os pólos positivos, cor azul, para a superficie. Cavidade central larga e aquosa. B. Visão de uma seç̧ão das paredes do canal coloridas de acordo com as suas propriedades fisicas: azul, zonas carregadas positivamente, vermelho, zonas negativas e amarelo zonas hidrofóbicas. (Retiradas da referência 2).

Estes últimos são versões truncadas dos primeiros faltando-lhes os segmentos S1 a S4. A arquitectura do canal é em qualquer dos casos sempre um tetrâmero de monómeros idênticos que se organizam em torno de um poro, no qual as S6 (interiores) e S5 (exteriores) são sempre as envolventes do poro central.

A sequência de aminoácidos do canal mais simples (KcsA) é muito idêntica à sequência dos dois últimos segmentos dos canais mais complexos (KvAP e canais das células eucarióticas), em especial na zona do poro e, também, em duas camadas de resíduos aromáticos situadas à superfície da membrana, nas interfaces entre os meios intra e extracelulares e a bicamada estendendo-se estes resíduos pelo interior hidrofóbico da membrana.

A figura $1 \mathrm{~A}$ e $\mathrm{B}$ mostra duas vistas do canal KcsA K+ que apareceram no artigo original da Science. Na vista de topo pode ver-se o poro do canal no centro das quatro subunidades (representadas cada uma por uma cor diferente). Na vista lateral pode observar-se que cada subunidade tem duas hélices transmembranares, a S6 mais interior que está no centro do canal e que tem um ângulo de entrada de cerca de $25^{\circ}$ relativamente ao eixo perpendicular à membrana (figura $1 \mathrm{C}$ ) e a S5 mais exterior, em contacto com o meio hidrofóbico da bicamada e que a atravessa pratica- mente (anti)paralela à S6 (figura 1 D). Estas duas hélices estão ligadas por uma sequência de 30 aminoácidos organizados em três domínios distintos, uma estrutura extracelular "turret", uma meia hélice "pore helix" e a sequência "assinatura" da qual faz parte o filtro de selectividade. A sequência "assinatura" tem 5 aminoácidos: treonia $T$, valina $V$, glicina G, tirosina Y e glicina G (TVGYG), em que apenas 3 são visíveis na figura 1 $\mathrm{D}$ e determina a zona mais estreita do canal. As hélices S5 e S6 estão posicionadas de tal modo na membrana que segundo MacKinnon parecem pétalas de uma flor a abrirem-se para o meio extracelular com as S6 a entrecruzarem-se no interior citoplasmático. As meias hélices partem do meio extracelular quase paralelas às S6, comportando-se como dipolos, estando o pólo negativo orientado para o centro do canal e estabelecem interacçōes com o resto da proteína de modo a estabilizar a estrutura tridimensional (figura $1 \mathrm{C}$ ). A sequência característica TVGYG está no interior das hélices S6 e das meias hélices (figura 1 D).

0 canal central formado pelos 4 monómeros tem cerca de $40 \AA$ de comprimento e está dividido em duas zonas distintas (figura 2 A). Entrando pelo meio extracelular aparece o filtro de selectividade, a zona mais estreita do canal com $2.8 \AA$ de raio e $12 \AA$ de comprimento. $O$ filtro desemboca na cavida- de central, de paredes hidrofóbicas, que está em contacto com o meio citoplasmático, e tem $28 \AA$ de comprimento e $10 \AA ̊$ de raio na sua zona mais larga. A abertura da cavidade para o meio intracelular é controlada por vários factores (voltagem, ligandos e outros processos mediados por nucleótidos cíclicos intracelulares), podendo assim o canal estar fechado (inactivo), quando a abertura desta cavidade é mínima, ou aberto (activo), quando a abertura é máxima, chegando a atingir $12 \AA$.

As duas entradas do canal, quer do lado citoplasmático, quer do lado extracelular, apresentam à superficie da membrana uma elevada densidade de cargas negativas, tornando-as muito electronegativas e portanto atractivas para a entrada de um catião. Em particular, na entrada extracelular encontram-se enterrados à superfície da bicamada 4 cargas negativas (por subunidade) provenientes de cadeias laterais de dois aminoácidos acídicos (glutâmico e aspártico).

$\mathrm{Na}$ figura $2 \mathrm{~B}$ pode ver-se a superfície do canal colorida de acordo com as suas propriedades físicas. Assim áreas a azul referem-se a zonas carregadas positivamente, seguindo-se as zonas a branco e terminando nas vermelhas que indicam zonas carregadas negativamente. No interior do canal as zonas a amarelo representam as paredes com caracteristicas hidrofóbicas da cavidade central. 
A

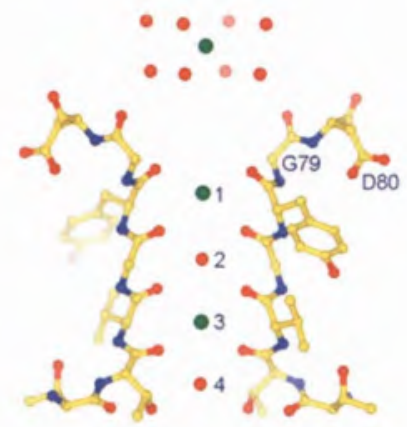

B

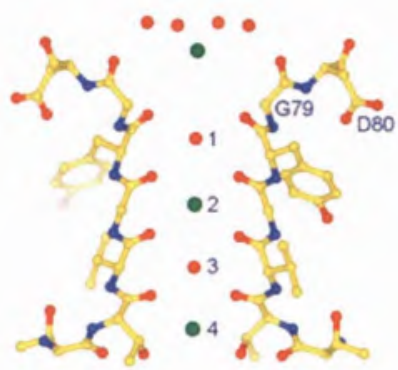

C

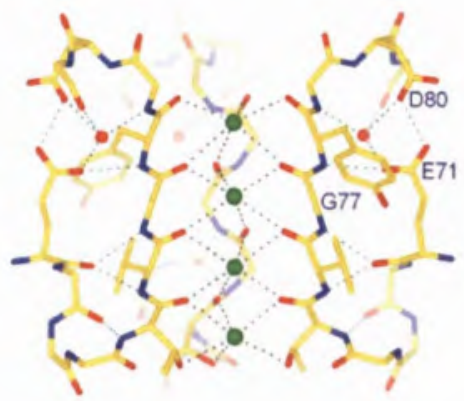

figura 3 Filtro de selectividade com 4 posições possiveis para o ião $\mathrm{K}$. A. Ião $\mathrm{K}$ à entrada extracelular com 8 moléculas de água coordenadas e dentro do filtro de selectividade 2 iôes $\mathrm{K}^{*}$ nas posiçôes 1 - 3 e 2 moléculas de água nas posiçōes 2 - 4. B. lão K à entrada extracelular parcialmente desidratado devido à presença de grupos carbonilo à entrada do poro e 2 iōes $K$ nas posições 2 - 4 e 2 moléculas de água nas posições 1 - 3 . C. Coordenação de 4 iōes $K^{*}$ no interior do filtro de selectividade, em que cada ião está localizado no centro de 8 átomos de oxigénio. (Retirada da referência 3).

\section{Filtro de Selectividade}

Mackinnon e colaboradores verificaram em 2001 (3) que o filtro de selectividade apresenta à entrada extracelular 4 grupos carbonilo $(-\mathrm{C}=0$, de 4 glicinas, uma de cada monómero) capazes de retirar metade das camadas de hidratação do ião, ajudando na desidratação ou hidratação dos iões que entram ou saem do filtro (figura 3). Os 5 aminoácidos da "assinatura" (TVGYG) que forram a parte mais estreita do poro apresentam para o seu interior os grupos carbonilo da sua cadeia principal e desviam para o interior da membrana os seus resíduos que estabelecem interacções com o resto da proteina. Assim, no interior do filtro existem os grupos carbonilo necessários à estabilização do $\mathrm{K}^{+}$dentro do canal, determinando a especificidade para o ião. 0 diâmetro do canal ( 2.8 Å) permite a optimização das interacções entre os oxigénios dos grupos - $\mathrm{C}=\mathrm{O}$ e $\circ \mathrm{K}^{*}$ impossibilitando no entanto que as mesmas se possam estabelecer com iões mais pequenos (como o $\mathrm{Na}^{+}$). Este diâmetro parece ser consequência directa das interacções (van der Waals ou pontes de $\mathrm{H}$ ) que os resíduos dos 5 aminoácidos estabelecem com o resto da proteina (visto estarem orientados para as hélices e meias hélices e não para o centro do canal) e da presença dentro do canal do próprio ião K . Mackinnon e colaboradores verificaram que o diâme- tro do filtro diminuía drasticamente em estruturas obtidas em meios com concentrações muito baixas de potássio (o filtro quase colapsava), tendo concluído então que não eram só os aminoácidos da "assinatura" que determinavam o diâmetro do canal, mas também a presença do ião $\mathrm{K}^{+}$dentro do mesmo. Sugeriram então que esta diminuição de diâmetro observada em concentrações baixas de $\mathrm{K}^{+}$poderia estar ligada ao fenómeno da rectificação observado em experiências de electrofisiologia. Assim, as taxas de permeação de $\mathrm{K}^{\star}$, medidas quando o fluxo se processa do meio exterior (onde a $\left[\mathrm{K}^{*}\right]$ é baixa) para o interior (onde a [ $\left.\mathrm{K}^{+}\right]$é elevada), são muito mais baixas que as medidas em sentido contrário.

Embora dentro do filtro existam 4 posições ( 1 a 4) possiveis para o K*, só duas podem ser ocupadas simultaneamente (1-3 ou 2-4), sendo as outras duas ocupadas por moléculas de água. Assim, dentro do filtro existem simultaneamente só 2 iões de $\mathrm{K}$ 'separados por 1 molécula de água. A selectividade do canal é conferida pelo seu filtro (grupos carbonilo e dipolos) e a rápida condução é conseguida à custa da repulsão electrostática que se verifica quando um terceiro ião entra dentro do canal.

\section{Cavidade Central}

A cavidade central que liga o filtro de selectividade ao meio intracelular tem $28 \AA ̊$ de comprimento e $10 \AA \AA$ de diâmetro e está hidratada, criando um ambiente favorável ao $\mathrm{K}^{+}$(de elevada constante dieléctrica contrastando com o interior da bicamada lipídica, figura 2 A). No centro da cavidade e na direcção da entrada do filtro de selectividade existe um ião $K^{*}$; que se mantém hidratado com 8 moléculas de água ordenadas (4 acima e 4 abaixo do ião), existindo no resto da cavidade mais moléculas de água desordenadas chegando-se a atingir uma $\left[\mathrm{K}^{+}\right] \approx 2 \mathrm{M}$. 0 posicionamento do ião no centro da cavidade e na direcção do filtro de selectividade, assim como a presença à entrada do filtro dos pólos negativos das 4 meias hélices, favorecem a entrada no filtro do ião residente na cavidade. A superfície da cavidade está forrada por resíduos com características hidrofóbicas, não havendo, pois, qualquer interacção entre estas paredes e o $\mathrm{K}^{+}$ou a água, facilitando, assim, a passagem do ião para o filtro.

Devido à inclinação com que as hélices S6 e S5 atravessam a bicamada, a entrada citoplasmática da cavidade central é muito estreita quando o canal não está activado, pois as extremidades das hélices S6 entrecruzam-se fechando o canal (figura $1 \mathrm{C}$ ). A abertura dá-se por afastamento destas extremidades quan- 
figura 4. Canal KVAP com 6 hélices S1 a S6. As S5 e S6 são as mais interiores e os sensores de voltagem $\mathrm{S} 3 b-\mathrm{S} 4$ (a vermelho) as mais exteriores. A ligação S4 - S5 "linker" sente o movimento dos sensores de voltagem $e$ transmite-o às hélices S5 e S6 provocando nestas alterações conformacionais e a consequente abertura ou fecho do canal. A. Canal inactivo com sensores no interior da camada bilipídica perto do meio citoplasmático. B. Canal activado, sensores movimentam-se e aproximam-se da superficie extracelular. (Retirada da referência 5).

figura 5: Modelo que exemplifica os dois estados do canal associados à posição dos sensores de voltagem. As cargas positivas da hélice S4 provocam uma corrente "gating current" no seu movimento através da membrana. A. Canal inactivo, fechado. B. Canal activo, aberto. (Retirado da referência

do o canal é activado (por voltagem, ligandos ou processos intracelulares).

\section{Activação do Canal por Afastamento das Hélices S6}

0 entrecruzamento das 4 hélices S6 provoca o fecho da cavidade central correspondendo esta configuração a uma forma inactiva do canal. Quando o canal é activado, há um afastamento dos terminais das S6 criando-se uma abertura de 12 Å de diâmetro da cavidade central para o lado citoplasmático. Esta abertura só é possivel devido à flexibilidade das hélices S6 que Ihes é conferida pela presença de um resíduo de glicina a meio da hélice. A glicina é o aminoácido que tem o grupo lateral mais pequeno $\mathrm{e}$ a sua presença confere às proteínas uma grande mobilidade nesse ponto (comporta-se como uma dobradiça). Assim, se for aplicada uma força lateral às hélices $\mathrm{S6}$, os seus terminais intracelulares afastam-se surgindo uma continuidade entre a cavidade central e o meio citoplasmático reduzindo-se ao fil-

$$
\text { A }
$$

B
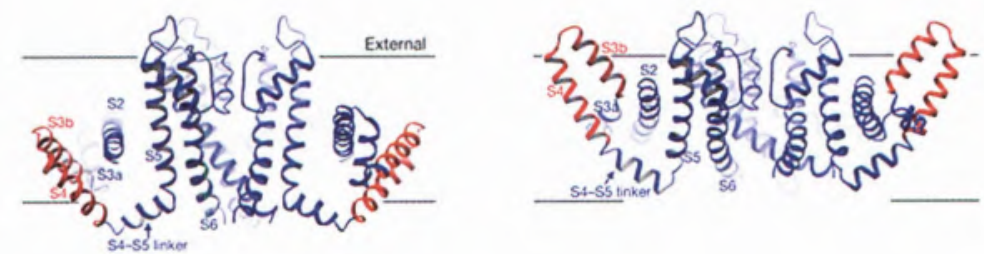

A

B
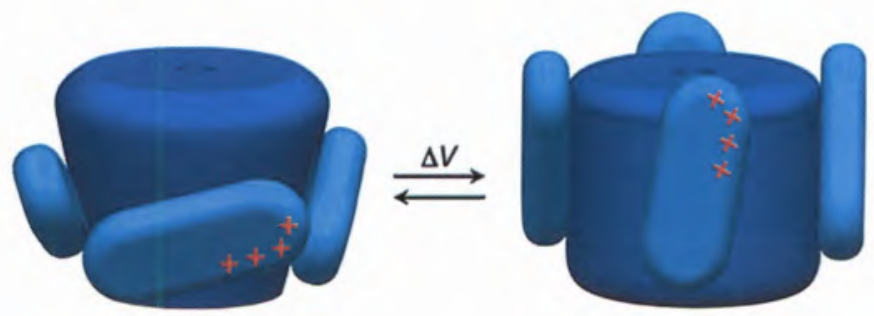

tro de selectividade a zona de permeação do canal. Verifica-se que há uma conservação desta glicina (dobradiça) em todos os canais de $\mathrm{K}^{+}$actualmente conhecidos, assim como há a conservação de um outro resíduo (alanina ou glicina) a uma distância de 5 aminoácidos da dobradiça e mais próximo do meio intracelular. Devido à localização particular deste segundo aminoácido na S6, o seu resíduo está apontado para o interior da cavidade o que determinaria que, se a sua dimensão não fosse suficientemente pequena, a abertura da cavidade ficasse bloqueada mesmo quando o canal estivesse activado.

\section{Sensores Voltagem}

Nos artigos publicados na revista Nature já em $2003(4,5)$, Mackinnon e colaboradores tentaram obter a estrutura de um canal com 6 segmentos (S1 a S6) tendo verificado que a obtenção de cristais de várias destas proteínas era muito difícil, possivelmente devido à grande mobilidade dos primeiros 4 segmentos, obtendo-se em geral agregados de tetrâmeros impossibilitando, assim, a cristalização. Sabendo desta dificuldade e depois de uma pesquisa exaustiva, conseguiram finalmente cristalizar canais de $\mathrm{K}^{+}$de uma arqueo bactéria termofilica Aeropyrum pernix KvAP e com estes estudos pretenderam elucidar fundamentalmente os mecanismos envolvidos na activação dos canais por voltagem.

Verificaram para estes canais KvAP que toda a região do poro (filtro de selectividade e cavidade central) era idêntica à descrita anteriormente e que, tal como no canal KcsA, as hélices S5 (exterior) e S6 (interior) eram as envolventes do canal condutor e mantinham as mesmas estruturas antiparalelas. Mackinnon e colaboradores sugeriram então que o movimento de abertura do canal provocado pelo afastamento dos terminais citoplasmáticos da S6 a partir da glicina (dobradiça), devia ser acompanhado por igual movimento das S5, sendo que o conjunto se moveria como um bloco. 
A estrutura mostrou que as restantes hélices (S1 a S4) se encontram mais afastadas do centro do poro. Na camada concêntrica seguinte à S6-S5 encontram-se as hélices S1 e S2, sendo a localização mais afastada do centro a das S3 e S4 (figura 4 A e B para canal inactivo e activo respectivamente). Verificaram no entanto que, contrariamente ao previsto anteriormente, o segmento S3 não é constituido por uma só hélice, mas sim por 2 hélices, as \$3a e \$3b, ligadas por uma ansa "loop". A S3b por sua vez está intimamente ligada por uma ansa ao terminal amino da S4 e este conjunto tem características muito hidrofóbicas (exceptuando 5 resíduos, argininas, carregados positivamente, distribuídas pela S4). MacKinnon e colaboradores verificaram que estes conjuntos S3b-S4 dos 4 monómeros eram os sensores de voltagem e baptizaram-nos de pás sensores de voltagem, "voltage sensor padles". Descreveram-nos de acordo com as suas características de polaridade, carga e estrutura secundária como sendo hidrofóbicos, catiónicos, hélice-dobra-hélice.

Estudos sobre a estrutura dos sensores mostraram que estes são móveis podendo adoptar diversas configurações. Os sensores estão limitados pela ansa (flexível) de ligação entre S3a e S3b no seu $\mathrm{N}$ terminal e por uma curva apertada mas flexivel na sua ligação (por uma glicina) à S5 no seu terminal C. A mobilidade destes sensores permite-Ihes uma grande liberdade de movimentos relativamente ao resto da proteína.

$\mathrm{Na}$ estrutura cristalina do canal inactivo os sensores de voltagem encontram-se no perímetro exterior do canal, no interior da bicamada, localizados perto do lado citoplasmático. Quando o canal está activo, estudos electrofisiológicos mostraram que determinados aminoácidos da S4 se ligavam a toxinas quando estas eram aplicadas no exterior. Estas observaçōes sugerem que no processo de activação do canal os sensores conseguem percorrer distâncias muito longas através da bicamada $(\approx 20 \AA)$, desde o seu interior na vizinhança do lado intracelular para o exterior da mesma, arrastando as suas cargas através da membrana e expondo ao meio extracelular parte da sua estrutura. Assim, os sensores de voltagem comportam-se como catiões hidrofóbicos ligados a alavancas que, respondendo a variações do campo eléctrico, se deslocam a grandes distâncias provocando alteraçōes conformacionais ao nivel da ligaçẩo S4-S5, que são sentidas pelas hélices S5 e S6, que se movem em bloco, causando a abertura ou fecho dos canais.

As alterações de voltagem, que activam o canal, provocam o movimento das cargas positivas da \$4 (argininas, figura 5) originando uma pequena corrente, "gating current", cuja existência já tinha sido prevista há 50 anos por Hodgkin. As hélices S2 possuem, por seu lado, resíduos acídicos que possivelmente servem para estabilizar as cargas das argininas quando estas se movimentam através da bicamada.

\section{Rigidez Versus Flexibilidade da Proteína}

Assim, a rigidez da proteina na vizinhança do filtro de selectividade é uma característica necessária à discriminação dos iōes em função dos tamanhos (conduz $\mathrm{K}^{+}$mas não $\mathrm{Na}^{+}$), contrastando com a flexibilidade observada nos sensores de voltagem e nas porçôes citoplasmáticas das hélices S5 e S6 envolvidas nos processos de activação do canal.

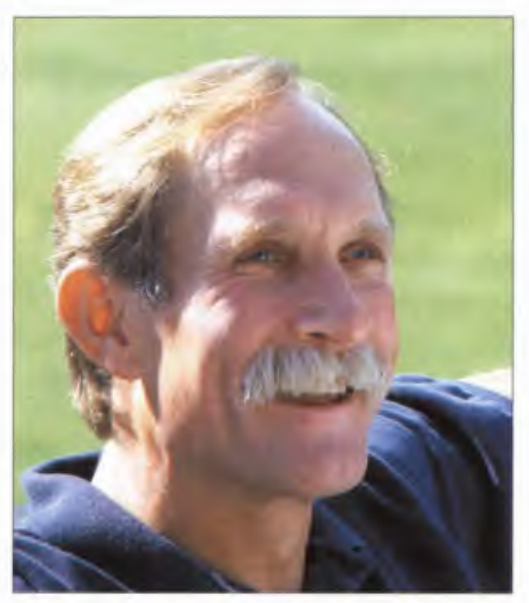

Peter Agre

"pela descoberta do canal de água"

\section{Canal de água - Peter Agre}

A água é o componente mais abundante do nosso organismo, constituindo cerca de $60 \%$ do peso total e estando distribuida internamente entre os compartimentos intra e extracelulares, separados pelas membranas celulares. Sendo estas em geral muito permeáveis à água, verifica-se que há isotonicidade (igual concentração de água) em praticamente todas as áreas do organismo (exceptuando algumas zonas no rim).

O volume dos vários compartimentos internos é muito sensível aos gradientes osmóticos através das membranas celulares e a sua regulação é essencial pois certas estruturas estão alojadas em compartimentos rígidos, como é o caso do sistema nervoso central (alojado na caixa craniana e canal vertebral), e de certos órgãos sólidos que estão rodeados por cápsulas fibrosas inextensiveis (rim e figado). 0 aumento de volume destas células pode determinar a compressão dos vasos sanguíneos e comprometer a irrigação necessária à sua sobrevivência.

O sistema urinário tem como função a regulação do volume, composição e pH do meio interno de todo o organismo, removendo para o exterior os produtos do metabolismo, os excessos de água, sal, $\mathrm{H}^{+}$e de outros electrólitos do plasma eliminando-os na forma de urina. Para isso, os rins formam cerca de $180 \mathrm{l} / \mathrm{dia}$ de filtrado (plasma sem proteínas) e eliminam cerca $1.5 \mathrm{l} / \mathrm{dia}$ sob a forma de urina, reabsorvendo, portanto, mais de $99 \%$ do filtrado. Sendo as flutuações da osmolalidade do espaço extracelular (e, portanto, do plasma sanguíneo) nos mamiferos muito pequenas, isso significa que a maior parte das trocas verificadas entre o meio exterior e o interior do organismo são praticamente isotónicas.

Os dois exemplos expostos (controlo de volume de compartimentos e reabsorção de grandes volumes de filtrado no rim) demonstram a existência de dois mecanismos de transporte de água distintos, o das trocas através de membranas celulares, em que as moléculas de água se movem independentemente dos iōes, e outro mais complexo através de paliçadas de células (epitélios), cujos mecanismos físicos ainda não estão esclarecidos e que envolve o movimento das moléculas de água ligadas aos movimentos de sal. 
figura 6 Estrutura do Tetrâmero de AQP1, em que cada monómero está representado por uma cor diferente. É visivel para o monómero cinzento as 6 hélices transmembranares 1 a 6 $e$ as duas meias hélices das ansas B e E. A. Vista de topo. B. Vista lateral. (Retirada da referência 8).
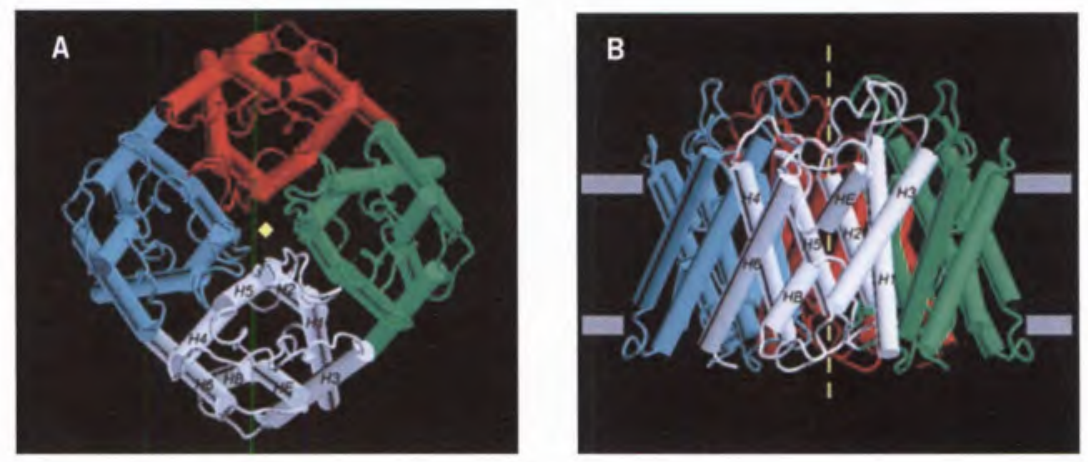

Sabe-se hoje que, embora as camadas bilipídicas sejam em geral muito permeáveis à água, existem muitas células do organismo cujas membranas celulares contêm canais específicos para o transporte de água, e que em alguns casos a inserção destes canais está sob controlo hormonal (hormona antidiurética).

A identificação da estrutura proteica (aquaporina, AQP) responsável pelo transporte de água em glóbulos vermeIhos foi feita pelo grupo de Peter Agre no início da década de 90 , embora já se soubesse da existência destes canais desde os anos 50. Esta descoberta permitiu a identificação desta família de proteínas nas várias células do organismo, o aprofundamento do seu estudo através de experiências de mutagénese e, mais recentemente, a determinação da sua estrutura cristalográfica com a consequente visualização dos mecanismos de selectividade e rápida condução.

Actualmente estão descritas mais de dez AQPs distribuídas por diferentes células do organismo tendo sido a AQP1 a primeira a ser identificada nas membranas do glóbulo vermelho e mais tarde nas do túbulo proximal do rim de mamífero. Actualmente sabe-se que as AQPS estão amplamente distribuídas pelas células dos vários órgãos, mas a sua função específica ainda não é clara, sabendo-se, no entanto, que devem ter um papel relevante na regulação do volume celular, estando ainda em discussão na comunidade científica o seu envolvimento nos movimentos transepiteliais referidos anteriormente.

\section{Transporte de água - Estudos funcionais}

Desde os anos cinquenta e muito antes da identificação das AQPs que se estuda o transporte de água através das membranas celulares (6). Foram estabelecidos ao longo dos anos os critérios usados para a detecção da presença de canais de água funcionais nas membranas celulares, passando estes pela avaliação das permeabilidades osmótica e difusional e das energias de activação para o transporte na presença e ausência de inibidores específicos. Na ausência de canais, a água movimenta-se só pela via bilipídica sendo a energia de activação medida para o transporte elevada e as permeabilidades osmótica e difusional iguais. Na presença de canais funcionais a energia de activação é baixa, a permeabilidade osmótica é superior à difusional e sabe-se actualmente que a sua razão é uma medida do $n$. $^{\circ}$ de moléculas de água dentro do canal.

A primeira evidência para a existência de canais no glóbulo vermelho surgiu na década de cinquenta quando um grupo de Harvard dirigido por A.K. Solomon verificou que a permeabilidade osmótica era superior à difusional. Passados um pouco mais de dez anos (finais dos anos sessenta) o grupo de R. Macey em Berkeley descreveu a acção inibidora de reagentes mercúricos (em especial o catião sulfonato de $p$-fenil de mercúrio $\|$, PCMBS), tendo demonstrado que a energia de activação para o transporte osmótico passava de um valor baixo para um elevado, quando os canais eram inibidos. No início da década de oitenta eram escassos na literatura os estudos de transporte difusional, visto as técnicas disponiveis para a sua medição serem de muito difícil execução e os resultados pouco reprodutiveis. Discutiase então na comunidade científica o mecanismo de permeação da água através destes canais. Estava em questão se estes eram largos, não selectivos e se o fluxo de água poderia ser considerado laminar (tese defendida pelo grupo de Solomon), ou se, pelo contrário, o canal era selectivo para a água (excluindo todos os outros solutos, incluindo o protão), sendo o mecanismo de transporte o de difusão em fila única (ideia defendida pelo grupo de R. Macey, com o qual eu já colaborava). Para a resolução desta questão era, no entanto, necessário desenvolver uma estratégia experimental que passasse pela avaliação conjunta das permeabilidades osmótica e difusional em células tratadas com concentraçōes diferentes de um inibidor que fechasse os canais de um modo tudo ou nada e cujo efeito no transporte de outros solutos fosse também avaliado. Surgiu por essa altura na literatura um artigo sobre a possível aplicação da técnica de RMN à medição de permeabilidades difusionais e, estando eu integrada na Universidade Nova de Lisboa no grupo do Prof. António Xavier, tive a oportunidade única de discutir com ele essa possibilidade. Foi assim que, em colaboração com a Prof. Helena Santos, então integrada no grupo do Prof. António Xavier, fizemos um conjunto de experiências que nos permitiram propor em 1984 que o canal de água era específico para a água, estreito (diâmetro $\approx$ 

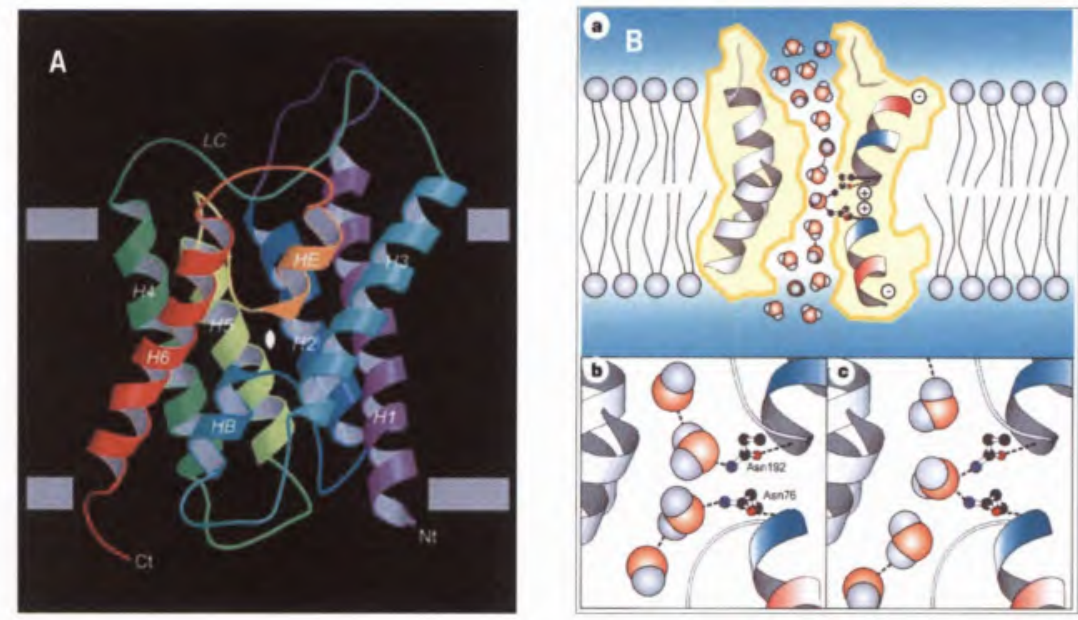

molécula de água) e que o mecanismo de transporte era por difusão em fila única, com cerca de $\mathbf{1 1}$ moléculas de água por canal. Sugerimos também que a exclusão do $\mathrm{H}^{+}$deveria estar relacionada com a presença de cargas positivas dentro do canal e/ou com a impossibilidade das moléculas de água formarem um contínuo dentro do canal, impossibilitando, assim, um mecanismo de Grötus.

Em meados dos anos oitenta começaram a aparecer também as primeiras evidências experimentais para a presença de canais de água nas células do túbulo proximal do rim, baseadas em medições de energia de activação e na inibição parcial do transporte osmótico observado por reagentes mercúricos.

\section{Identificação do canal de água e respectiva estrutura}

A identificação do canal foi uma descoberta fortuita feita em 1987 por Peter Agre até então um hematologista a investigar antigénios da membrana de eritrócitos. Ao purificar um antigénio dos grupos Rh obteve como contaminante uma proteina de $28 \mathrm{kDa}$ muito abundante nos eritrócitos, (160 mil cópias por célula), que até então nunca tinha sido detectada pelos fisiologistas da altura por não corar com azul de Coomassie (o corante mais usado na detecção de proteinas). Estava-se na época em que no glóbulo vermelho já haviam sido identificados quase todos os transportadores existentes, faltando só a identificação da estrutura proteica (tão procurada pelos fisiologistas), responsável pelo transporte de água: "o canal de água".

Peter Agre e seus colaboradores demonstraram em 1992 (7) que a então membrane protein", era o tão procurado canal de água da membrana do eritrócito, o qual foi posteriormente também identificado como o canal de água das células do túbulo proximal do rim de mamífero. Exprimiram a CHIP28 em oócitos de Xenopus, cujas membranas são muito impermeáveis à água, e verificaram que estes começavam a inchar quando imersos em água contrariamente a oócitos controlo que não tinha sido injectados. Observou-se na mesma altura que a reconstituição de fracções purificadas de CHIP28 em lipossomas sintéticos induzia um grande aumento da permeabilidade à água, tendo-se calculado que cada canal transportava cerca de $3 \times 10^{\circ}$ moléculas de água por segundo. A estrutura quaternária da proteína foi visualizada por microscopia electrónica em fragmentos membranares contendo CHIP28, tendo-se observado que esta formava tetrâmeros. Em 1993 Agre propôs o nome aquaporina, ficando o tetrâmero de CHIP28 a ser conhecido por AQP1, no qual cada subunidade é um canal de água.

\section{Estrutura do monómero da AQP1}

A figura 6 A e B mostra duas vistas (topo e lateral) da estrutura do tetrâmero de AQP1, publicada por um grupo de investigadores em colaboração com Agre em chamada CHIP28 "Channel like integral figura $7 \mathrm{~A}$. Vista lateral de um monómero de $A Q P 1$. É visível a localizaçâo citoplasmática dos terminais amino e carboxilico e a grande aproximação no centro do canal entre os terminais $N$ (Asn) das duas meias hélices (HE e HB). B. Representação esquemática do mecanismo de reorientação das moléculas de água ao nivel dos dipolos (das meias hélices) que provoca a quebra de pontes de H entre moléculas de água vizinhas, bloqueando assim a passagem do protâo. (Retirada da referência 8).

2000 (8), em que cada monómero está representado com uma cor diferente. Cada monómero da AQP1 tem 269 aminoácidos organizados por 6 hélices transmembranares ligadas por 5 ansas identificadas por letras ( $A$ a $E$ ) e com duas sequências Asn-Pro-Ala (NPA) conservadas em todas as AQPs conhecidas. Por experiências de mutagénese foram identificados em 1993 dois residuos na vizinhança próxima das sequências NPA, a cisteína Cys189 (na ansa E) responsável pela inibição do canal provocada pelo PCMBS e a alanina Ala73 (na B) que, quando substituída por outro resíduo de maiores dimensões, causava uma inibição idêntica à do PCMBS. Foram estes dados que em 1993 levaram à proposta de que, se o canal era específico só para a água, a sua zona de constrição deveria estar localizada perto das sequências NPA e foi postulado que o canal deveria ter a forma de uma ampulheta.

A partir dos dados de estrutura de cada monómero pôde constatar-se que as hélices estão organizadas em dois grupos distintos (2, 1, 3, e 5, 4, 6), que se juntam, formando um canal interior (figura 7 A e 7 B). No primeiro grupo, as hélices 1 e 2 atravessam a bicamada quase paralelas entre si, num ângulo de $25^{\circ}$ relativo ao eixo perpendicular ao plano da membrana e a hélice 3 apresenta uma inclinação de cerca de $40 .^{\circ}$ em sentido oposto, sendo a situação idêntica no outro grupo. A estabilização deste conjunto é feita a partir de interacções estabelecidas entre resíduos de hélices vizinhas, e da presença, nas zonas de 
figura $8 \mathrm{~A}$. Monómero de $\mathrm{AQP1}$ onde estão sobrepostos imagens instantâneas da trajectória de uma molécula de água resultantes de simulaçōes moleculares dinâmicas com duração de 3.3 ns. No interior do canal são visiveis cerca de 11 moléculas de água. A coloração amarela da superficie refere-se a paredes capazes de interagir com moléculas de áqua. B. Representação em fita onde são visiveis vários aminoácidos no interior do canal envolvidos directamente no processo da condução saltatória. (Retirada da referência 9) contacto entre hélices, do resíduo mais pequeno, a glicina.

Sabe-se também que as NPA são sequências terminais de duas meias hélices, (existentes em segmentos das duas ansas $B$ e E), que partem de faces opostas da superfície da membrana em ângulos de inclinação semelhantes $\left(\approx 35 .^{\circ}\right)$ e, ao atingirem o centro da bicamada, projectam para o interior do canal os grupos amido dos resíduos $\mathrm{N}$ terminais (Asn192 e Asn76). Estas duas meias hélices em conjunto, ao contrário das outras, parecem formar uma sétima hélice transmembranar torcida. As forças que mantêm os grupos amido tão próximos um do outro e no centro do canal, são interacções de van der Waals entre as duas Prolinas das sequências NPA e a formação de um par iónico a cerca de $5 \AA$ Å de distância entre a His74 da meia hélice B e o Glu17 da hélice 1.

\section{Estrutura clarifica o Mecanismo de Permeação e a Especificidade do Canal à água}

Um tetrâmero de AQP1 tem quatro canais, sendo os canais totalmente específicos para a água e o transporte de água extremamente rápido $\left(\approx 3 \times 10^{9} \mathrm{~s}^{-1}\right)$. Assim, a AQP1, para além de excluir qualquer soluto de dimensões superiores a $2.8 \AA$, exclui também o protão.

Teoricamente, se o transporte de água em fila única permitisse às moléculas de água a formação de pontes de hidrogé-

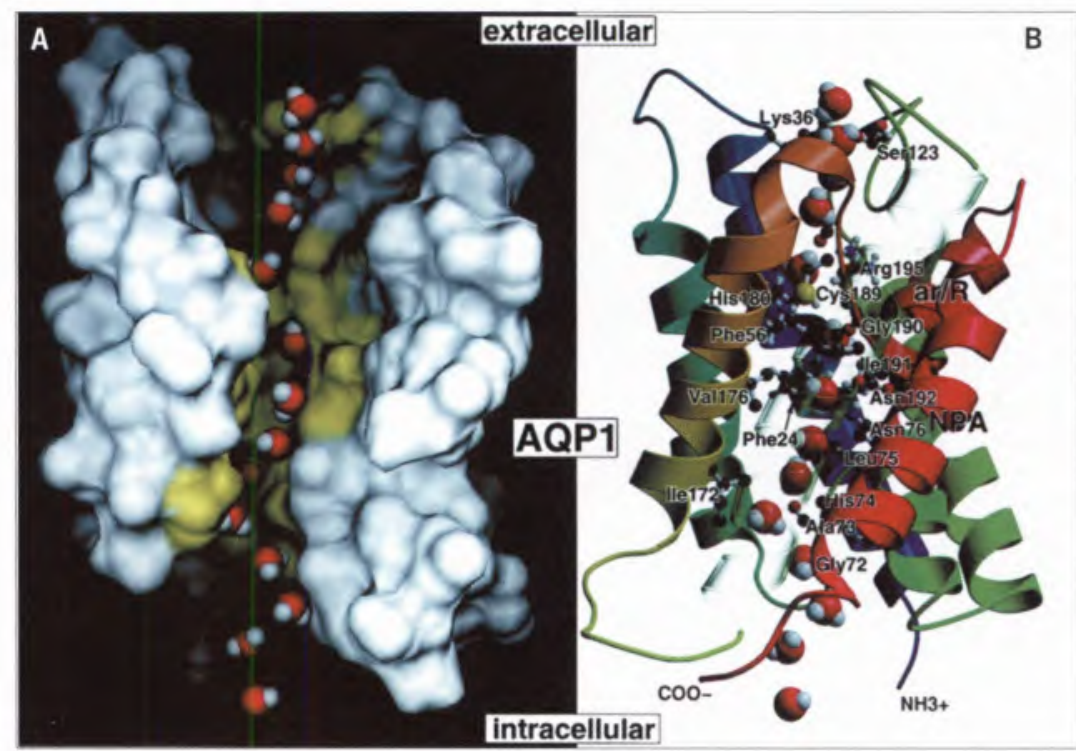

nio ao longo de todo o comprimento do canal, isso permitiria que a condução do protão fosse extremamente rápida, (mecanismo de Grötus). Este mecanismo para o transporte do protão foi verificado experimentalmente em canais de gramicidina (antibiótico) incorporados em membranas artificiais.

A resolução da estrutura do canal de água feita por este grupo de investigadores em colaboração com Agre em 2000 (8) veio confirmar as nossas propostas feitas em 1984: mecanismo por difusão em fila única para o transporte de água através dos canais; inibição do transporte tudo ou nada provocada pelo PCMBS, e causas de exclusão do transporte do protão pela AQP1.

\section{Filtros de Selectividade e Interacções entre Moléculas de Água e Parede do Canal}

Groot e Grubmüller do Instituto Max Plank em Göttingen em 2001 (9), a partir de modelos de simulação dinâmica molecular da permeação de moléculas de água em tempo real, observaram a elevada taxa de transporte de água. 0 modelo que desenvolveram foi baseado nos dados estruturais da AQP1 e nas muito baixas energias de activação para o transporte medidas. A figura $8 \mathrm{~A} \mathrm{e} \mathrm{B}$ mostra a localização dentro do canal das moléculas de água, quando se sobrepōem as imagens instantâneas obtidas por simulação dinâmica do trajecto de uma só molécula. Pela observação da figura $8 \mathrm{~B}$ pode acompanhar-se passo a passo o trajecto percorrido pelas moléculas de água e verificar as interacções, que esta estabelece com as paredes do canal, durante esse percurso.

Entrada do canal pelo lado intracelular: A entrada é larga permitindo interacções entre as várias moléculas de água. Segue-se uma zona mais estreita onde as moléculas de água conseguem estabelecer interacções com as paredes do canal, com grupos carbonilo da cadeia principal dos resíduos Gly 72, Ala 73 e His $\mathbf{7 4}$, que precedem a sequência NPA da meia hélice $\mathbf{B}$.

Entrada do canal pelo lado extracelular: Nesta entrada existem os resíduos Lys $\mathbf{3 6}$ na ansa $\mathbf{A}$ e Ser 123 na ansa C, capazes de interagir com as moléculas de água. Tal como descrito para o lado intracelular, existem também interacções entre as moléculas de água e grupos carbonilo da cadeia principal dos resíduos Cys 189, Gly 190 e lle 191, situados antes das sequências NPA da meia hélice $\mathbf{E}$. A presença do resíduo de Cys 189 , que se projecta para dentro do poro, sugere que a inibição do transporte, observada com PCMBS, é devida à oclusão do canal, tal como foi sugerido em 1984.

Região ar/R - $1 .{ }^{\circ}$ Filtro de selectividade: Do lado extracelular e a cerca de $8 \AA$ do centro da bicamada, estão projectados para o interior do canal três resíduos vo- 
lumosos, His 180, Phe 56 e Arg 195 , que criam a zona mais estreita do canal com cerca de $2.8 \AA$ A de diâmetro. Esta zona exclui, assim, todas as moléculas de diâmetro superior. A carga positiva da Arg 195 neste local é também uma barreira à passagem de catiōes, incluindo o protão. 0 carácter hidrofóbico do resíduo da Phe $\mathbf{5 6}$ obriga a que a molécula de água se reoriente para se afastar deste resíduo e se aproximar da $\mathbf{A r g}$ 195 e da His 180 , estabelecendo com estes fortes interacções.

Região NPA - 2. ${ }^{\circ}$ Filtro de selectividade: As duas meias hélices têm caracteristicas especiais de dipolo com os pólos positivos muito próximos orientados para o centro do canal. 0 campo electrostático resultante obriga à reorientação dos dipolos das moléculas de água, de modo a que o átomo de oxigénio destas se aproxime dos grupos amido dos resíduos Asn 192 e Asn 76 das sequências NPA, favorecendo a formação de pontes de $\mathrm{H}$ (figura $7 \mathrm{~B}$ ). A presença, na parede oposta do canal, de um resíduo volumoso hidrofóbico, a Phe 24, ajuda à reorientação da molécula de água, favorecendo a sua interacção com as duas Asn. A reorientação dos dipolos da água à passagem pelas sequências NPA, quebra eventuais pontes de $\mathrm{H}$ que as moléculas de água pudessem ter estabelecido com outras moléculas vizinhas. Assim, o campo electrostático formado pelas meias hélices impede a passagem do protão por um mecanismo de Grötus e repele o protão por este ter carga positiva, servindo como um $2 .^{\circ}$ filtro à sua passagem.

Zonas Hidrofóbicas da parede do canal: Existem duas zonas hidrofóbicas no interior do canal, nas quais os resíduos da parede são incapazes de estabelecer interacções com moléculas de água. A primeira zona situa-se entre os dois filtros, zonas ar/R e NPA (dipolos), e a segunda entre estes e a entrada intracelular. Os residuos hidrofóbicos da parede da primeira zona são Phe 56, Ile 191 , Val 176, e da segunda são lle 60 , Leu 75. Val 79 e Leu 149. A passagem das moléculas de água por estas zonas é extremamente rápida, pois estas não conseguem interagir com estes resíduos das paredes do canal.

\section{Mecanismo e Dinâmica da AQP1 - Condução Saltatória}

Mecanismo por difusão em fila única: 0 canal tem cerca de $20 \AA$ de comprimento e $3 \AA$ de diâmetro na sua zona mais estreita, o suficiente para permitir a passagem de moléculas de água. Das simulações dinâmicas moleculares pôde observar-se que as moléculas permanecem em fila única, havendo cerca de $\mathbf{1 1}$ moléculas de água dentro do canal, tal como previsto em 1984 (figura 8 A).

Condução Saltatória: No interior do canal o movimento das moléculas de água assemelha-se a um movimento saltatório, em que as moléculas saltam de interacção em interacção, passando rapidamente pelas zonas hidrofóbicas do canal onde essas interacções não são possiveis. Entrando pelo lado extracelular, as interacções entre moléculas de água e residuos de parede iniciam-se com a Lys 36 e Ser 123, seguindo-se os resíduos hidrofilicos da região $\operatorname{ar} / \mathrm{R}$. De imediato, as moléculas de água praticamente saltam desta zona para a zona dos dipolos, pois, entre ambos, estendese a primeira zona hidrofóbica. Quando chegam à zona dos dipolos há a reorientação das moléculas, quebrando qualquer ponte de $\mathrm{H}$ que possam ter estabelecido com moléculas vizinhas. Ao saírem desta zona, o movimento das moléculas é de novo acelerado para que a nova travessia de um ambiente hidrofóbico seja rápida, permitindo chegar a zonas mais favoráveis. Na entrada intracelular do canal, as moléculas podem interagir entre si dado que esta é uma entrada larga. Daí parecer que as moléculas de água, ao percorrerem o canal, saltam de interacção em interacção, numa espécie de Condução Saltatória.

Rapidez de transporte: 0 movimento colectivo de moléculas de água, que baixa drasticamente a energia de activação, parece ser o responsável pelas elevadas taxas de condução medidas.

\section{Notas}

'Todas as figuras retiradas das referências estão autorizadas pelos respectivos editores.

\section{Bibliografia}

1. Bertil Hille

Ionic Channels of Excitable Membranes

Editores Sinauer Associates Inc. $2{ }^{\circ}$ ediçāo (1992).

2. Doyle, D., Morais Cabral, J., Pfuetzner, R., Kuo, A., Gulbis, J., Cohen, S., Chait, B.,

Mackinnon, $R$.

The structure of the potassium channel: molecular basis of $\mathbf{K}^{+}$conduction and selectivity

Science 280, 69 - 77 (1998).

3. Zhou, Y., Morais Cabral, J., Kaufman, A., Mackinnon, R.

Chemistry of ion coordination and hydration revealed by a $\mathrm{K}^{*}$ channel - Fab complex at 2.0 Å resolution.

Nature 414, 43 - 48 (2001).

4. Jiang, Y., Lee, A., Chen, J., Ruta, V., Cadene, M., Chait, B., MacKinnon, R.

$\mathrm{X}$-ray structure of a voltage dependent $\mathrm{K}^{+}$ channel

Nature 423, 33 - 41 (2003).

5. Jiang, Y., Ruta, V., Chen, J., Lee, A., MacKinnon, R.

The Principal of gating charge movement in a voltage dependent $\mathbf{K} \cdot$ channel

Nature 423, 41 - 48 (2003).

6. Alan Finkelstein

Water movement through lipid bilayers, pores and plasma membranes

Editores Wiley InterScience (1987).

7. Preston, G. M., Carroll, T.P., Guggino, W.B. \& Agre, P.

Appearance of water channels in Xenopus oocytes expressing red cell CHIP28 protein Science 256, 385 - 387 (1992).

8. Murata, K., Mitsuoka, K., Hirai, T., Walz, T., Agre, P., Heymann, J.B., Engel, A., Fujiyoshi, $Y$.

Structural determinants of water permeation through aquaporin -1

Nature 407, 599 - 605 (2000).

9. Groot, B., Grubmüller, H.

Water Permeation Across Biological Membranes: Mechanism and Dynamics of Aquaporin-1 and GIpF

Science 294, 2353 - 2357 (2001). 


\section{Subscribe Now!}

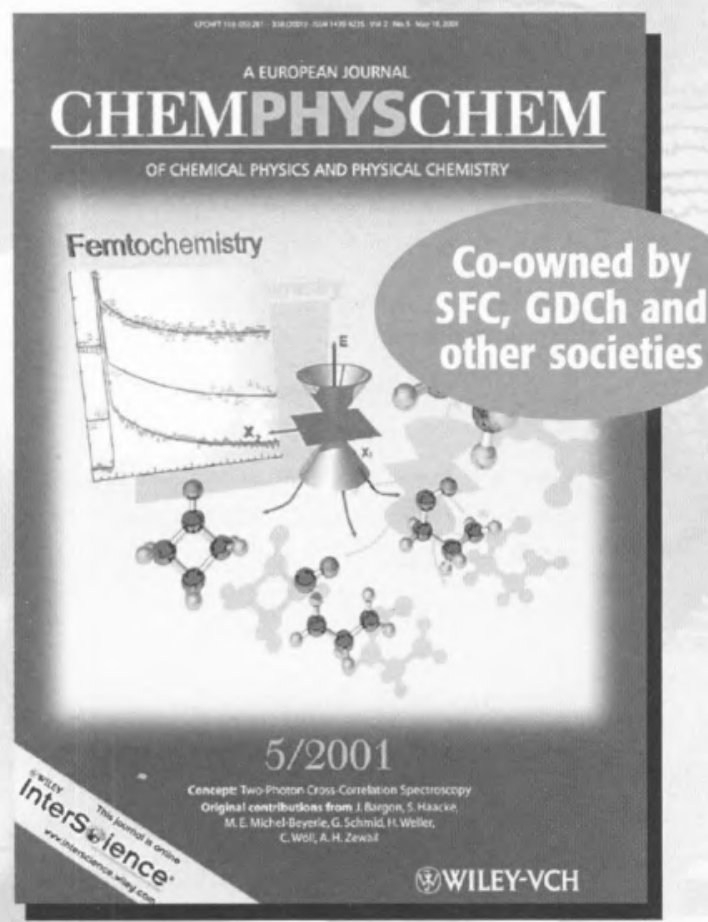

\section{ChemPhysChem}

A European Journal of Chemical Physics and Physical Chemistry

2002 Volume 3,12 issues per year,

ISSN Print 1439-4235

ISSN Electronic 1439-7641
ChemPhysChem - Where Chemistry Meets Physics Meets Chemistry...

ChemPhysChem amalgamates the wide and flourishing field ranging - to name just a few topics -

- from atmospheric science to hard and soft condensed matter

- from femtochemistry to nanotechnology

- from complex biological systems to single molecule research

- from clusters and colloids to catalysis and surface science

- from electro- to photochemistry

\section{Papers from distinguished scientists} worldwide, such as
Z. I. Alferoy
G. Ertl
C. A. Mirkin
C. Amatore
C. Friend
C. N. R. Rao
C. D. Bain
J. S. Kilby
J.-M. Savéant
V. Balzani
H. Kroemer
R. J. Saykally
C. Bräuchle
R. Lavery
G. Wegner
E. A. Carter
J.-M. Lehn
C. Zannoni
A. Corma
R. D. Levine
R. N. Zare
F. C. De Schryver
H. Matsuhara
A. H. Zewail

Available as a separate journal and as a part of attractive packages with Angewandte Chemie (Int. Ed.) Please visit www.chemphyschem.com
Virtual Sample Copy: FREE online access to full text of sample copy: www.interscience.wiley.com
Please enter my/our 2002 subscription to ChemPhysChem
At the institutional rate*:

$\begin{array}{ll}\text { print } & \text { electronic } \\ \in \text { 598,- } & \square \in \text { 598,- } \\ \text { sFr 1028,- } & \square \mathrm{sFr} 1028,- \\ \text { US } \$ 648,- & \square \text { US\$ 648,- } \\ \text { * For a 5\% premium, institutions can also } \\ \text { choose both print and online access }\end{array}$

At the personal member rate:

$$
\text { print }
$$

$\square \in 148,-$

$\square$ sFr 248,-

US\$ 158,-
Europe

Switzerland

All other countries
Please tick: $\square$ private $\square$ business

\section{Please send me a free sample copy}

Please return this order form to your local bookseller or to:

Customers in Germany, Austria, and Switzerland:

WILEY-VCH Reader Service

P. O. Box 101161

D. 69451 Weinheim, Germany

Phone: +49 (0) $6201-606147$

Fax: +49 (0) 6201-606 172

e-mail: subservice@wiley-vch.de
Customers in all other areas: John Wiley \& Sons, Ltd. Journals Administration Department 1 Oldlands Way Bognor Regis West Sussex, PO22 9SA, UK Phone: +44 (0) 1243-779 777 Fax: +44 (0) 1243-843232 e-mail:cs-journals@wiley.co.uk 